\title{
Sarcoma of the Orbit pTX TNM Finding v7
}

National Cancer Institute

\section{Source}

National Cancer Institute. Sarcoma of the Orbit PTX TNM Finding v7. NCI Thesaurus.

Code C88811.

Sarcoma of the orbit in which the primary tumor cannot be assessed. (from AJCC 7th Ed.) 